\title{
Pengaruh Profitabilitas, Leverage, Dan Ukuran Perusahaan Terhadap Pengungkapan Corporate Social Responsibility
}

\author{
Prasisca Riezky Maharani*, Tri Kartika Pertiwi \\ Program Studi Manajemen, Fakultas Ekonomi dan Bisnis, \\ Universitas Pembangunan Nasional "VETERAN" Jawa Timur \\ e-mail: prasisca1@gmail.com
}

\begin{abstract}
This research aims to find out the effect of Profitability, Leverage, and Company Size on CSR Disclosure on companies listed in the kompas100 Index in 2018-2019. The population in this study is a company listed in kompas 100 index in 2018-2019 with purposive sampling techniques so that 140 companies are listed in the kompas 100 index as samples. The type of data used is secondary data by using documentation methods as data collection. The data analysis techniques used are the outlier test, normality test, multicollinearity test, heteroskedasticity test, autocorrelation test, multiple linear regression analysis, hypothesis test. The results of this study showed that Profitability and Corporate Size did not contribute to CSR Disclosure, while Leverage contributed to CSR Disclosure in companies listed in kompas 100 Index in 2018-2019. All these independent variables simultaneously contribute to CSR Disclosure.
\end{abstract}

Keywords: CSR Disclosure, profitability, leverage, company size, kompas 100 index, IDX

\begin{abstract}
Abstrak
Penelitian ini bertujuan untuk mengetahui pengaruh Profitabilitas, Leverage, dan Ukuran Perusahaan terhadap Pengungkapan CSR pada perusahaan yang terdaftar di Indeks Kompas100 tahun 2018-2019. Populasi dalam penelitian ini yaitu perusahaan yang terdaftar di Indeks Kompas100 tahun 2018-2019 dengan teknik pengambilan sampel purposive sampling sehingga diperoleh 140 perusahaan yang terdaftar di Indeks Kompas 100 sebagai sampelnya. Jenis data yang digunakan adalah data sekunder dengan menggunakan metode dokumentasi sebagai pengumpulan data. Teknik analisis data yang digunakan adalah uji outlier, uji normalitas, uji multikolinearitas, uji heteroskedastisitas, uji autokorelasi, analisis regresi linier berganda, uji hipotesis. Hasil penelitian ini menunjukkan bahwa Profitabilitas dan Ukuran Perusahaan tidak memberi kontribusi terhadap Pengungkapan CSR, sedangkan Leverage memberi kontribusi terhadap Pengungkapan CSR pada perusahaan yang terdaftar di Indeks Kompas100 tahun 2018-2019. Seluruh variabel independen tersebut secara simultan memberi kontribusi terhadap Pengungkapan CSR.
\end{abstract}

Kata kunci: Pengungkapan CSR, profitabilitas, leverage, ukuran perusahaan, indeks kompas 100, IDX 


\section{PENDAHULUAN}

Sejatinya, perusahaan dibangun dan berdiri di tengah lingkungan masyarakat. Kegiatan operasional perusahaan pun mau tidak mau harus bisa fokus pada nilai dan norma yang berlaku di masyarakat dan dampaknya terhadap lingkungan agar tidak menimbulkan konflik. Sebagai contoh kasus perusahaan yang terjadi di Indonesia adalah PT Timah Tbk tahun 2018-2019 yang melakukan reklamasi pasca penambangan di Desa Mapur, Kecamatan Riausilip, Kabupaten Bangka dengan lahan tambang sebesar 100 ha. Namun, hanya 10 hektar saja yang telah direklamasi dan sisanya dibiarkan kosong (Gunadha, 2020). Ada pula aktivitas penambangan PT Vale Indonesia Tbk pada akhir tahun 2018 juga menunjukkan bahwa lahan bekas tambang mengakibatkan peningkatan sedimen dan terbentuklah lahan baru yang dipenuhi lumpur di pinggiran Danau Mahal (AlAmin, 2018).

Fenomena kasus yang terjadi diatas merupakan bagian dari perusahaan yang terdaftar di Indeks Kompas100 yang mengindikasikan bahwa tanggung jawab sosial yang dilakukan oleh perusahaan belum maksimal. Hal ini diperkuat dengan rata-rata pengungkapan CSR dari perusahaan yang terdaftar di indeks kompas 100 pada tahun 2019 sedikit lebih rendah daripada tahun 2018 yaitu rata-rata tahun 2018 sebesar 0,262 dan rata-rata tahun 2019 sebesar 0,246. Oleh sebab itu, perusahaan diharapkan untuk lebih meningkatkan kesadarannya dengan lebih memperhatikan lingkungan dan mempertimbangkan tanggung jawab yang terkait dengan sosial sebagai akibat dari kegiatan operasional yang dilaksanakan.

Sebagaimana yang diungkapkan oleh (Vanessa \& Meiden, 2020) bahwa idealnya, perusahaan harus mampu melakukan berbagai aksi sosial secara transparan sebagai bentuk kontribusinya untuk memberikan perlindungan terhadap lingkungan dan sumber daya alam. Kontribusi tersebut dapat diwujudkan melalui Corporate Social Responsibility (CSR). Rokhlinasari dalam Vanessa \& Meiden (2020) mengatakan bahwa perusahaan menjalankan tanggung jawab sosial dimaknai sebagai bentuk komitmen jangka panjang untuk berperan secara aktif serta bertindak sesuai dengan hukum, nilai, dan norma yang ada agar dapat membantu membangun ekonomi serta meningkatkan taraf hidup bagi lingkungan dan para pemangku kepentingan. CSR juga dapat diartikan sebagai cara perusahaan mengelola kegiatan operasionalnya dalam menghasilkan produk agar memiliki dampak positif bagi dirinya dan lingkungan sekitar. Diharapkan dengan adanya konsep CSR tersebut, dapat membantu agar kerusakan lingkungan yang terjadi di Indonesia dapat diminimalisir.

Perusahaan yang melaksanakan kegiatan CSR perlu mengungkapkannya agar dapat dijadikan sebagai sarana untuk membantu mengkomunikasikan dampak lingkungan dan sosial dari kegiatan ekonomi perusahaan kepada pihak pemangku kepentingan. Dengan mengungkapnya, perusahaan dapat memperoleh manfaat seperti mendapatkan citra positif, dapat menumbuhkan rasa kepercayaan kepada stakeholders, dan membantu meningkatkan nilai perusahaan. Meningkatnya nilai perusahaan menjadi daya magnet tersendiri bagi pihak investor untuk menginvestasikan dananya di perusahaan (Rizaldi et al, 2019). Kemudian dana investasi itu dapat digunakan perusahaan untuk menunjang kegiatan operasional sehingga diharapkan keberlangsungan hidup perusahaan dapat berjalan dalam jangka panjang. 
Penelitian ini menggunakan beberapa faktor yang disinyalir dapat mempengaruhi pengungkapan CSR seperti profitabilitas, leverage, dan ukuran perusahaan. Profitabilitas ialah rasio yang digunakan untuk memperlihatkan seberapa besar perusahaan mampu mendatangkan laba. Perusahaan yang memiliki tingkat profitabilitas tinggi akan dianggap mampu untuk membiayai atau mendanai pelaksanaan dan pengungkapan kegiatan CSR. Sebagaimana yang (Dewi \& Sari, 2019) temukan bahwa berdasarkan teori stakeholder, apabila profitabilitas perusahaan tinggi akan membuat manajer memiliki dukungan untuk melaksanakan dan mengungkapkan CSR akibat adanya alokasi dana yang lebih banyak untuk kegiatan CSR. Leverage ialah rasio yang seringkali berguna bagi perusahaan untuk mendanai aktivitas operasional menggunakan hutang. Menurut (Rofiqkoh \& Priyadi, 2016) perusahaan dengan leverage tinggi wajib untuk mengungkapkan kegiatan CSR secara transparan daripada perusahaan dengan leverage rendah agar dapat diyakini oleh pihak kreditur bahwa perusahaan mampu melunasi kewajibannya sebelum masa habis waktunya sehingga perusahaan mau tidak mau herus memberikan informasi mengenai kondisinya termasuk informasi CSR secara luas.

Selanjutnya ada ukuran perusahaan yang mengacu pada perusahaan besar maupun kecil. Besarnya perusahaan menandakan bahwa perusahaan tersebut memiliki banyak pengalaman dan ide serta laba yang lebih besar dan nantinya akan dimanfaatkan untuk mengembangkan bisnisnya (As'ari \& Pertiwi, 2021). Perusahaan yang besar juga biasanya akan memperoleh perhatian atau sorotan lebih dari masyarakat sehingga pihak manajemen akan berusaha mengungkapkan informasi terutama mengenai aktivitas tanggung jawab sosialnya lebih luas lagi guna mendapatkan kepercayaan dari pihak pemangku kepentingan (Vanessa \& Meiden, 2020). Penelitian ini menggunakan perusahaan yang terdaftar di Indeks Kompas 100 sebagai subyek penelitian karena di dalamnya terdapat 100 saham teratas di bursa efek indonesia yang mempertimbangkan faktor likuiditas, kapitalisasi pasar, kinerja fundamental yang baik serta ingin melihat perusahaan secara umum dan tidak dikhususkan pada sektor tertentu.

Penelitian ini bertujuan untuk mengetahui pengaruh Profitabilitas, Leverage, dan Ukuran Perusahaan terhadap Pengungkapan CSR pada perusahaan yang terdaftar di Indeks Kompas100 tahun 20182019

\section{TINJAUAN PUSTAKA}

\section{Corporate Social Responsibility}

CSR didefinisikan sebagai rasa tanggung jawab sosial perusahaan dengan lingkungan sekitar melalui kegiatan sosial agar mampu mendatangkan manfaat yang dapat dirasakan bagi perusahaan, masyarakat, dan lingkungan sekitar dan apabila kegiatan tersebut dilaksanakan secara terus-menerus maka akan menjadi bentuk pembangunan ekonomi berkelanjutan. Sebagaimana Mandaika dan Salim (2015) temukan bahwa konsep CSR membuat perusahaan tidak lagi fokus pada single bottom line, namun berganti menjadi triple bottom lines. Konsep triple bottom lines tersebut bisa disingkat seperti 3P yaitu profit, people, dan planet. Ketiga prinsip itu menjelaskan bahwa kegiatan CSR tidak hanya mengarah pada laba atau keuntungan saja, namun juga harus dapat memperhatikan kebutuhan dan keinginan masyarakat, karyawan, dan lingkungan sekitar. 
Seperti yang telah diatur dalam UndangUndang No. 40 tahun 2007 pasal 74 ayat 1, Tanggung Jawab Sosial Perusahaan atau Corporate Social Responsibility merupakan salah satu bentuk ketentuan perusahaan dalam menjalankan kegiatan usahanya di bidang dan atau berkaitan dengan sumber daya alam untuk wajib melaksanakan tanggung jawab sosial dan lingkungan guna meningkatkan taraf hidup masyarakat. Secara tidak langsung perusahaan diharapkan dapat melakukan aktivitas sosial sebagai bentuk kontribusinya dalam rangka melestarikan sumber daya alam sekaligus meningkatkan kualitas kehidupan lingkungan sekitar.

\section{Teori Stakeholders}

Seperti yang dikatakan oleh (Cahyaningtyas, 2018) teori stakeholders mengasumsikan bahwa bagaimanapun juga perusahaan dalam menjalankan kegiatannya tidak untuk kepentingan dia sendiri namun harus dapat mendatangkan manfaat bagi para stakeholdersnya, seperti pemegang saham, kreditur, konsumen, supplier, pemerintah, masyarakat, analis dan pihak lain. Apabila perusahaan tidak melibatkan stakeholders maka akan menimbulkan masalah seperti mendapat teguran dan tidak diakui oleh para stakeholder. Dengan demikian, perusahaan harus mampu memenuhi kepentingan dan keinginan dari stakeholders untuk dapat mempertanggungjawabkan kegiatan operasionalnya karena dukungan dari stakeholders akan mempengaruhi keberlangsungan hidup perusahaan dalam jangka waktu yang panjang.

\section{Teori Legitimasi}

Teori legitimasi merupakan teori yang terbentuk karena fenomena sosial antara organisasi / perusahaan dengan masyarakat, dimana tujuan keduanya sama-sama harus sejalan dengan nilai dan norma yang berlaku di lingkungan masyarakat. Karena perusahaan berdiri di tengah lingkungan masyarakat, maka perusahaan harus berusaha meyakinkan jika kegiatan operasionalnya sudah berjalan sesuai dengan norma yang ada sehingga akan mampu mendapatkan legitimasi dari masyarakat. Namun ketika ada ketidaksesuaian antara kedua belah pihak, maka timbullah risiko negatif berupa tidak diakui atau dipercaya oleh masyarakat (Ratmono \& Sagala, 2016).

\section{Teori Keagenan}

Menurut Wardani dalam (Rofiqkoh \& Priyadi, 2016) Teori keagenan atau bisa disebut agency theory ialah teori yang mengungkapkan adanya hubungan antara principal (pemilik perusahaan) dan agent (manajer perusahaan) berdasarkan adanya pemisahan kepemilikan dan pengendalian perusahaan, pemisahan penanggung resiko, pembuatan keputusan, dan pengendalian fungsi-fungsi. Agent maupun principal memiliki wewenang dan tanggung jawab yang ada di dalam kontrak kerja berdasarkan keputusan bersama (Rokhlinasari, 2016). Oleh karena itu, apabila wewenang dan tanggung jawab tidak sebanding maka akan menimbulkan konflik kepentingan diantara mereka.

Konflik terjadi dikarenakan manajer tidak berjalan sesuai dengan apa yg perusahaan inginkan sehingga timbullah biaya agen. Sebagai contoh: manajer memiliki tanggung jawab utk meningkatkan laba para pemilik perusahaan dan memaksimalkan nilai perusahaan, namun disisi lain manajer pastinya menginginkan untuk mendapatkan kompensasi sesuai dengan kontrak. Begitupun dengan pengungkapan CSR ini. Pengungkapan informasi terkait corporate social responsibility pastinya memiliki 
tujuan untuk membangun image atau reputasi perusahaan yang positif di mata stakeholders. Untuk dapat melaksanakan pengungkapan informasi mengenai tanggung jawab sosial pun, perusahaan memerlukan biaya sehingga perusahaan akan melaporkan laba tahun berjalan menjadi lebih rendah (Rokhlinasari, 2016). Sebagaimana yang diungkapkan oleh Febrina dan Suaryana dalam (Rofiqkoh \& Priyadi, 2016) dimana teori keagenan mengatakan bahwa perusahaan yang mendatangi biaya kontrak dan biaya pengawasan yang rendah maka akan melaporkan labanya lebih rendah atau akan mengeluarkan biaya-biaya untuk kepentingan manajemen, salah satunya yaitu biaya-biaya yang terkait dengan tanggung jawab sosial perusahaan agar dapat meningkatkan image atau reputasi perusahaan di mata stakeholder. Oleh karena itu, manajer sebagai agen akan lebih berusaha untuk memenuhi seluruh keinginan dari principal atau perusahaan seperti memberikan informasi tambahan kepada investor berupa mengungkapkan informasi tanggung jawab sosial perusahaan agar dapat membantu mengalihkan perhatian dalam pengawasan manipulasi laba atau lainnya.

\section{Profitabilitas}

Menurut Kasmir dalam (Dewi \& Dita, 2016) mengungkapkan bahwa rasio profitabilitas merupakan rasio untuk menilai kemampuan perusahaan dalam mencari keuntungan. Rasio ini juga bisa memberikan takaran mengenai keefektifan manajemen dari perusahaan. Selain itu, profitabilitas dapat diartikan sebagai kemampuan perusahaan memperoleh laba dalam hubungannya dengan penjualan, total aktiva, ataupun modal sendiri.

\section{Leverage}

Leverage merupakan rasio yang seringkali digunakan untuk mengukur kemampuan perusahaan dalam melakukan kegiatan operasional perusahaan menggunakan hutang. Hutang dapat dijadikan sebagai salah satu sumber pendanaan bagi perusahaan untuk melakukan ekspansi atau pengembangan perusahaan. Perusahaan yang menggunakan hutang terlalu tinggi dapat membuat perusahaan sulit untuk melepaskan beban hutangnya.

\section{Ukuran Perusahaan}

Menurut (Dewi \& Dita, 2016) ukuran perusahaan adalah skala yang menentukan apakah perusahaan itu besar atau kecil. Ukuran perusahaan biasanya diukur berdasarkan total aktiva yang dimiliki. Pengertian dari total aktiva adalah segala macam sumber daya yang dimiliki perusahaan yang diharapkan akan mendatangkan manfaat bagi perusahaan di masa depan. Perusahaan dengan aktiva yang besar akan mendapatkan banyak perhatian dari investor, pemerintah, kreditur, maupun masyarakat dibandingkan perusahaan yang memiliki aktiva dalam jumlah yang sedikit.

Tabel 1. Kriteria Sampel Penelitian

\begin{tabular}{|c|l|c|}
\hline No. & \multicolumn{1}{|c|}{ Keterangan } & Jumlah \\
\hline 1 & Perusahaan yang terdaftar di Indeks Kompas100 & 100 \\
\hline 2 & Perusahaan yang keluar dari Indeks Kompas100 pada tahun 2018-2019 & $(30)$ \\
\hline \multicolumn{2}{|c|}{ Jumlah perusahaan } & 70 \\
\hline
\end{tabular}

Sumber: Data Diolah, 2021 
Tabel 2. Sampel Penelitian

\begin{tabular}{|c|c|c|c|}
\hline No. & Perusahaan & No. & Perusahaan \\
\hline 1 & PT Astra Agro Lestari Tbk & 36 & PT Indocement Tunggal Prakarsa Tbk \\
\hline 2 & PT Ace Hardware Indonesia Tbk & 37 & PT Indosat Tbk \\
\hline 3 & PT Adhi Karya Tbk & 38 & PT Indo Tambangraya Megah Tbk \\
\hline 4 & PT Adaro Energy Tbk & 39 & PT Japfa Comfeed Indonesia Tbk \\
\hline 5 & PT Akr Corporindo Tbk & 40 & PT Jasa Marga Tbk \\
\hline 6 & PT Aneka Tambang Tbk & 41 & PT Kalbe Farma Tbk \\
\hline 7 & PT Astra International Tbk & 42 & PT Link Net Tbk \\
\hline 8 & PT Alam Sutera Reality Tbk & 43 & PT Matahari Department Store Tbk \\
\hline 9 & PT Bank Negara Indonesia Tbk & 44 & PT PP London Sumatra Indonesia Tbk \\
\hline 10 & PT Bank Rakyat Indonesia Tbk & 45 & PT Mitra Adiperkasa Tbk \\
\hline 11 & PT Bank Tabungan Negara Tbk & 46 & PT Medco Energi Internasional Tbk \\
\hline 12 & PT Bank Danamon Indonesia Tbk & 47 & PT Mitra Keluarga Karyasehat Tbk \\
\hline 13 & PT Bekasi Fajar Industrial Estate Tbk & 48 & PT Media Nusantara Citra Tbk \\
\hline 14 & PT BPD Jawa Barat dan Banten Tbk & 49 & PT Perusahaan Gas Negara Tbk \\
\hline 15 & PT Bank Pembangunan Daerah Jawa Timur Tbk & 50 & PT Bank Pan Indonesia Tbk \\
\hline 16 & PT Sentul City Tbk & 51 & PT PP Properti Tbk \\
\hline 17 & PT Bank Mandiri Tbk & 52 & PT Bukit Asam Tbk \\
\hline 18 & PT Global Mediacom Tbk & 53 & PT PP Tbk \\
\hline 19 & PT Bank CIMB Niaga Tbk & 54 & PT Pakuwon Jati Tbk \\
\hline 20 & PT Bank Permata Tbk & 55 & PT Ramayana Lestari Santosa Tbk \\
\hline 21 & PT Barito Pacific Tbk & 56 & PT Surya Citra Media Tbk \\
\hline 22 & PT Bumi Serpong Damai Tbk & 57 & PT Semen Indonesia Tbk \\
\hline 23 & PT Bumi Resources Tbk & 58 & PT Summarecon Agung Tbk \\
\hline 24 & PT Charoen Pokphand Indonesia Tbk & 59 & PT Sri Rejeki Isman Tbk \\
\hline 25 & PT Ciputra Development Tbk & 60 & PT Surya Semesta Internusa Tbk \\
\hline 26 & PT Elnusa Tbk & 61 & PT Sawit Sumbermas Sarana Tbk \\
\hline 27 & PT XL Axiata Tbk & 62 & PT Tower Bersama Infrastructure Tbk \\
\hline 28 & PT Gudang Garam Tbk & 63 & PT Timah Tbk \\
\hline 29 & PT Hanjaya Mandala Sampoerna Tbk & 64 & PT Telkom Indonesia Tbk \\
\hline 30 & PT Harum Energy Tbk & 65 & PT Chandra Asia Petrochemical Tbk \\
\hline 31 & PT Indofood CBP Sukses Makmur Tbk & 66 & PT United Tractors Tbk \\
\hline 32 & PT Vale Indonesia Tbk & 67 & PT Unilever Indonesia Tbk \\
\hline 33 & PT Indofood Sukses Makmur Tbk & 68 & PT Wijaya Karya Tbk \\
\hline 34 & PT Indika Energy Tbk & 69 & PT Waskita Beton Precast Tbk \\
\hline 35 & PT Indah Kiat Pulp \& Paper Tbk & 70 & PT Wijaya Karya Beton Tbk \\
\hline
\end{tabular}

Sumber: Data Diolah, 2021

\section{METODE PENELITIAN}

\section{Jenis Penelitian}

Metode yang dipergunakan dalam penelitian yaitu metode kuantitatif dengan pendekatan asosiatif. Seperti yang dikatakan oleh (Sugiyono, 2015) bahwa pendekatan asosiatif memiliki tujuan untuk mengetahui hubungan sebab akibat antara dua variabel atau lebih.

\section{Populasi dan Sampel}

Populasi yang dipergunakan penelitian ini ialah perusahaan yang terdaftar di Indeks Kompas100 tahun 2018-2019 
sejumlah 100 perusahaan. Sedangkan sampel yang dipakai sebanyak 70 perusahaan dalam satu tahun. Oleh karena penelitian ini menggunakan dua tahun maka perusahaan yang diamati menjadi 140 perusahaan.

\section{Metode Pengumpulan Data}

Metode penelitian ini menggunakan teknik pengumpulan data yaitu metode dokumentasi dengan data sekunder. Selain itu, teknik pengambilan sampel yang dipilih ialah teknik purposive sampling yang berdasarkan kriteria tertentu. Tabel 1 menununjukkan kriteria dari perusahaan yang dijadikan sampel.

Berdasarkan teknik pengambilan sampel tersebut, diperoleh 70 perusahaan sebagai sampel dengan jumlah pengamatan sebanyak 140 perusahaan. Berikut ini daftar sampel penelitian perusahaan yang terdaftar di Indeks Kompas100 tahun 20182019.

\section{Analisis Data}

Teknik analisis data yang diperlukan yaitu analisis regresi linier berganda. Sebelum masuk pada analisis regresi, terlebih dahulu dilakukan uji asumsi klasik dan uji outlier untuk memastikan agar persamaan regresi layak dan dapat dipercaya sebagai alat analisis yang representatif. Uji asumsi klasik yang dipakai ialah uji multikolinearitas, uji heteroskedastisitas, dan uji autokorelasi. Setelah itu, dilakukanlah uji hipotesis yaitu uji F dan uji-t.

\section{HASIL DAN PEMBAHASAN}

\section{Hasil}

Uji Outlier

Kriteria untuk mengevaluasi outlier dilakukan dengan melihat nilai mahalanobis distance yang didasarkan pada nilai chi- square. Jika nilai Mahal. Distance Maximum $>$ Prob. \& Jumlah variabel $[=\mathrm{CHIINV}(0,001 ; 4)$ maka data tersebut terdapat outlier. Berdasarkan hasil uji outlier pertama menunjukkan bahwa data terdapat outlier karena nilai Mahal. Distance Maximum $>$ Prob. \& Jumlah variabel $[=\operatorname{CHIINV}(0,001 ; 4)$ yaitu $31,755>18,467$, dimana ada outlier pada data tersebut yang berarti data ini memiliki kualitas yang tidak baik. Oleh karena itu, data perlu diuji kembali dan hasil dari uji outlier kedua menunjukkan bahwa nilai Mahal. Distance Maximum > Prob. \& Jumlah variabel $[=\operatorname{CHIINV}(0,001 ; 4)$ yaitu $17,741<18,467$, sehingga dapat disimpulkan bahwa tidak terdapat outlier dalam data dan dapat diolah lebih lanjut dengan 138 data yang memiliki kualitas baik.

\section{Uji Normalitas}

Uji normalitas dapat dikatakan normalitas apabila suatu persamaan regresi antara variabel terikat dan bebas atau keduanya memiliki distribusi yang normal. Uji ini menggunakan uji Kolmogorov Smirnov dengan tingkat signifikansi lebih besar dari 0,05 untuk mendeteksinya. Berdasarkan hasil uji, variabel Profitabilitas (X1) dan Leverage (X2) memiliki distribusi yang normal dimana nilai signifikansi lebih besar dari 0,05. Namun terdapat satu variabel yang tidak berdistribusi normal yaitu Ukuran Perusahaan (X3) dengan nilai signifikansi 0,000. Akan tetapi hasil dari uji kualitas data atau outlier menunjukkan bahwa tidak terdapat outlier pada data tersebut. Oleh karena itu, data ini memiliki kualitas yang baik dan dapat dilanjutkan untuk diolah lebih lanjut. Selain itu, berdasarkan "central limit of theorem" jumlah data yang diolah termasuk data besar, yaitu lebih dari 30 . Dengan demikian dapat diasumsikan bahwa data dianggap berdistribusi NORMAL (Sekaran, 2006). 


\section{Uji Multikolinearitas}

Uji multikolinearitas digunakan untuk melihat korelasi antar variabel bebas dengan batas pengukuran nilai variance inflation factor (VIF) dan tolerance value 10 dan 0,10. Apabila nilai VIF dibawah 10 dan dan tolerance value lebih dari 0,10 , artinya tidak ada multikolinearitas. Berdasarkan pengujian, nilai tolerance value dan VIF masing-masing variabel bebas lebih dari 0,10 dan VIF dibawah 10 yang menandakan bahwa tidak ada multikolineariitas dalam persamaan regresi.

\section{Uji Heteroskedastisitas}

Uji heteroskedastisitas dipakai guna menguji ada tidaknya kesamaan variabel terikat pada masing-masing variabel bebas dalam pengamatan. Berdasarkan hasil uji menggunakan korelasi rank spearman, diperoleh bahwa variabel bebas dengan residual tidak memiliki korelasi dimana nilai signifikansi lebih besar dari 0,05.

\section{Uji Autokorelasi}

Persamaan regresi dapat diartikan baik apabila tidak ada autokorelasi. Untuk mencari tahu model regresi ada tidaknya autokorelasi, maka dilakukanlah uji autokorelasi. Berdasarkan hasil analisis, menunjukkan nilai Durbin Watson sebesar 1,858 . Nilai Durbin Watson tabel dengan $n=$ 138 dan variabel bebas $(K)=3$ serta $\alpha=0,05$ maka $\mathrm{dL}=1,6778, \mathrm{dU}=1,7665$, dan 4-dU $=2,2335$. Maka dari itu, persamaan yang dipakai tidak ada autokorelasi karena memiliki Durbin Watson antara 1,7665 sampai dengan 2,2335.

\section{Analisis Regresi Linier Berganda}

Analisis regresi dipergunakan untuk menguji pengaruh lebih dari satu variabel independen terhadap variabel dependen (Ghozali, 2014). Setelah memenuhi atau lolos uji asumsi klasik seperti uji multikolinearitas, uji heteroskedastisitas, uji autokorelasi, serta data terdistribusi normal, maka diperoleh model persamaan regresi:

$$
\mathrm{Y}=\alpha+\beta_{1} \mathrm{X}_{1}+\beta_{2} \mathrm{X}_{2}+\beta_{3} \mathrm{X}_{3}+\mu
$$

Berdasarkan model regresi diatas maka persamaan regresi berganda yang diperoleh ialah:

$$
\mathrm{Y}=0,240-0,084 \mathrm{X} 1+0,011 \mathrm{X} 2-0,002 \mathrm{X} 3
$$

Konstanta bernilai sebesar 0,240 yang menandakan bahwa apabila tidak ada variabel independen seperti variabel profitabilitas, leverage, dan ukuran perusahaan maka pengungkapan corporate social responsibility memiliki nilai sebesar 0,240. Koefisien profitabilitas (X1) bernilai sebesar -0,084 menunjukkan jika nilai profitabilitas bertambah satu satuan maka akan mengalami penurunan sebesar 0,084, begitupun sebaliknya. Nilai koefisien leverage (X2) sebesar 0,011 mengartikan jika nilai leverage naik satu satuan maka akan mengalami kenaikan sebesar 0,011, begitupun sebaliknya. Nilai koefisien ukuran perusahaan (X3) sebesar -0,002 menandakan bahwa jika ukuran perusahaan bertambah satu satuan maka akan mengalami penurunan sebesar 0,002, begitupun sebaliknya.

Selanjutnya Uji t (parsial) dipergunakan untuk melihat dampak variabel bebas terhadap variabel terikat secara terpisah. Dalam penelitian ini uji $\mathrm{t}$ menggambarkan apakah profitabilitas, leverage, serta ukuran perusahaan mampu menjelaskan perubahan pengungkapan corporate social responsibility secara terpisah. Tingkat kepercayaan yang dipakai adalah 95\% dengan kesalahan 5\%. Berdasarkan tabel 1 diatas, hasil uji t dapat disimpulkan sebagai berikut.

Profitabilitas (X1) mempunyai nilai koefisien sebesar -0,084 dengan signifikansi 0,551 lebih dari $5 \%(0,551>0,05)$. Dapat diartikan bahwa profitabilitas memiliki pengaruh negatif dan tidak signifikan 
terhadap pengungkapan corporate social responsibility. Leverage (X2) mempunyai nilai koefisien sebesar 0,011 dengan signifikansi 0,007 kurang dari 5\% $(0,007<$ 0,05). Dapat diartikan bahwa leverage memiliki pengaruh positif dan signifikan terhadap pengungkapan corporate social responsibility. Ukuran perusahaan (X3) mempunyai nilai koefisien sebesar $-0,002$ dengan signifikansi 0,242 lebih dari 0,05 $(0,242>0,05)$. Dapat diartikan bahwa ukuran perusahaan memiliki pengaruh negatif dan tidak signifikan terhadap pengungkapan corporate social responsibility.

Pada tahapan Uji F dipergunakan untuk melihat keseluruhan variabel bebas mempunyai pengaruh secara serentak terhadap variabel terikat (Ghozali, 2014). Uji F dalam penelitian ini memperlihatkan apakah profitabilitas (X1), leverage (X2), dan ukuran perusahaan (X3) mampu menjelaskan perubahan pengungkapan corporate social responsibility.
Berdasarkan tabel 1 diatas menandakan besaran $F_{\text {hitung memiliki nilai sebesar } 4,587}$ dengan tingkat signifikansi sebesar 0,004 yang artinya dibawah 0,05 . Hal tersebut dapat diartikan ketiga varibel yaitu profitabilitas (X1), leverage (X2), dan ukuran perusahaan (X3) serentak memiliki kontribusi terhadap pengungkapan corporate social responsibility.

\section{Uji Kebaikan Model}

Koefisien determinasi penelitian ini memperlihatkan kesanggupan model dalam menjelaskan pengaruh variabel bebas terhadap variabel terikat.

Berdasar hasil pengujian tabel 1 diatas menjelaskan nilai $\mathrm{R}$ square $\left(\mathrm{R}^{2}\right)$ sebesar 0,093. Hal itu menandakan pengungkapan CSR yang dipengaruhi oleh variabel profitabilitas, leverage, dan ukuran perusahaan sebesar 0,093 atau $9,3 \%$ sedangkan sisanya $90,7 \%$ menjelaskan variabel lain yang tidak ikut diteliti.

Tabel 2. Hasil Analisis Regresi Linier Berganda, Uji t, dan Uji F

\begin{tabular}{|l|r|r|r|l|}
\hline \multicolumn{1}{|c|}{ Variabel } & \multicolumn{1}{c|}{ Beta } & t hitung & \multicolumn{1}{c|}{ P } & \multicolumn{1}{c|}{ Keterangan } \\
\hline Konstanta (b0) & 0,240 & 6,293 & & \\
\hline Profitabilitas (X1) & -.084 & -.597 & .551 & Tidak signifikan \\
\hline Leverage (X2) & .011 & 2.755 & .007 & Signifikan \\
\hline Ukuran Perusahaan (X3) & -.002 & -1.175 & .242 & Tidak signifikan \\
\hline $\begin{array}{l}\text { Adjusted R Square =0,073 } \\
\text { R Square = 0,093 }\end{array}$ & & & F tabel $=3,134$ t tabel $=1,655$ \\
R =0,305 & & & & \\
F hitung = 4,587 & & & & \\
SignifF=0,004 & & & & \\
\hline
\end{tabular}

Sumber: Data diolah, 2021

\section{Pembahasan}

Kontribusi Profitabilitas terhadap

Pengungkapan Corporate Social

Responsibility

Profitabilitas memiliki pengaruh negatif dan tidak signifikan terhadap Pengungkapan
Corporate Social Responsibility, yang artinya hipotesis 1 ditolak. Hasil ini tidak mendukung adanya teori stakeholder yang diungkapkan oleh (Dewi \& Sari, 2019) yang menyatakan bahwa meningkatnya profitabilitas perusahaan akan membuat 
perusahaan memiliki dukungan untuk melaksanakan dan mengungkapkan CSR sebagai akibat adanya alokasi dana yang lebih banyak untuk kegiatan CSR.

Perusahaan yang memiliki laba tinggi akan beranggapan bahwa perusahaan tidak perlu melakukan aksi sosial karena perusahaan cenderung akan fokus untuk mencari laba saja. Hal ini disebabkan aktivitas CSR yang dilakukan dan diungkapkan memerlukan pendanaan yang berasal dari sebagian keuntungan perusahaan. Sehingga tingkat profitabilitas yang tinggi juga tidak mendorong pada pengungkapan tanggung jawab sosial dikarenakan tingginya laba akan dimanfaatkan untuk memaksimalkan kegiatan perusahaan dalam hal pengembangan, kinerja, dan kebutuhan lain (Hestiningtyas, 2018). Hasil penelitian ini sejalan dengan (Respati \& Hadiprajitno, 2015) (Dewi \& Dita, 2016) dimana tingginya laba yang dimiliki oleh perusahaan bukan berarti perusahaan tersebut banyak melakukan kegiatan CSR karena bisa jadi perusahaan hanya fokus pada mendapatkan laba saja sehingga perusahaan tidak berupaya untuk mencari dukungan dari stakeholder melainkan hanya mencari cara untuk memperoleh laba semata.

\section{Kontribusi Leverage terhadap}

Pengungkapan Corporate Social Responsibility

Berdasarkan hasil pengujian, variabel Leverage memiliki pengaruh positif dan signifikan terhadap Pengungkapan Corporate Social Responsibility, hal ini sesuai dengan hipotesis yang kedua. Dimana hasil penelitian ini mendukung hasil penelitian (Rofiqkoh \& Priyadi, 2016) yang menyatakan rasio leverage dimanfaatkan untuk dapat menaruh gambaran mengenai struktur modal yang dimiliki oleh perusahaan sehingga dapat dilihat tingkat resiko tidak tertagihnya hutang. Semakin tinggi rasio leverage perusahaan maka akan mengakibatkan semakin tinggi jumlah hutang yang harus dibayar baik dalam jangka pendek maupun jangka panjang sehingga dapat meningkatkan resiko tidak tertagihnya hutang tersebut. Oleh karena itu, dibutuhkan tambahan informasi untuk menghilangkan keraguan dan menimbulkan kepercayaan kepada para stakeholder.

Hal ini sejalan dengan teori keagenan atau agency theory (Rofiqkoh \& Priyadi, 2016) dimana untuk dapat memenuhi keinginan dari perusahaan maka diperlukan informasi tambahan berupa pengungkapan informasi tanggung jawab sosial agar dapat membantu mengalihkan perhatian dalam pengawasan memanipulasi laba karena ketika perusahaan mengungkapkan informasi CSR, perusahaan memerlukan biaya sehingga cenderung akan melaporkan laba perusahaan lebih rendah. Maka dari itu, perusahaan yang memiliki rasio leverage tinggi wajib untuk melakukan pengungkapan lebih terbuka dan transparan daripada perusahaan dengan rasio leverage yang rendah (Rofiqkoh \& Priyadi, 2016).

\section{Kontribusi Ukuran Perusahaan terhadap Pengungkapan Corporate Social Responsibility}

Ukuran Perusahaan memiliki pengaruh negatif dan tidak signifikan terhadap Pengungkapan Corporate Social Responsibility, yang artinya hipotesis 3 ditolak. Hasil penelitian ini tidak sejalan dengan adanya teori legitimasi yang menyatakan bahwa keberadaan suatu organisasi atau perusahaan dapat terus berlanjut dan diterima jika perusahaan berjalan sesuai dengan nilai, norma, dan hukum yang berlaku di masyakarat agar perusahaan mendapatkan kepercayaan dan perhatian lebih dari masyarakat sehingga perusahaan akan lebih mudah untuk memperoleh dan mengungkapkan informasi. 
Sebagaimana yang dikatakan oleh (Vanessa \& Meiden, 2020) dimana besarnya perusahaan akan mendapatkan perhatian lebih dari masyarakat sehingga pihak manajemen akan mengungkapkan informasi terutama yang mengenai aksi tanggung jawab sosialnya secara lebih luas agar memperoleh kepercayaan dari pihak pemangku kepentingan seperti masyarakat dan investor.

Namun hasil penelitian ini sejalan dengan penelitian dari (Pakpahan, 2018) yang menyatakan bahwa ukuran perusahaan tidak memiliki pengaruh terhadap pengungkapan tanggung jawab sosial karena besar maupun kecilnya perusahaan, keduanya sama-sama menjadi perhatian atau sorotan masyarakat akibat dari dampak kegiatan operasional yang ditimbulkan sehingga besar kecilnya perusahaan pastinya memiliki kewajiban yang sama dalam melakukan pengungkapan tanggung jawab sosial. Ukuran perusahaan yang dihitung berdasarkan total aset mengindikasikan bahwa berapapun aset yang dimiliki oleh perusahaan, tidak akan mempengaruhi sedikit atau banyaknya tanggung jawab sosial perusahaan yang dilakukan.

\section{KESIMPULAN DAN SARAN}

\section{Kesimpulan}

Tujuan dari penelitian ini yaitu untuk mengetahui pengaruh dari Profitabilitas (X1), Leverage (X2), dan Ukuran Perusahaan (X3) terhadap Pengungkapan CSR. Penelitian ini menggunakan perusahaan yang terdaftar di Indeks Kompas 100 sebagai objek penelitian dengan sampel sebanyak 140 perusahaan. Hasil penelitian menyatakan bahwa profitabilitas dan ukuran perusahaan tidak mampu memberikan kontribusi terhadap Pengungkapan CSR dikarenakan perusahaan dengan profitabilitas tinggi merasa tidak perlu melakukan dan mengungkapkan kegiatan sosial seperti CSR kepada stakeholder sedangkan besar kecilnya perusahaan memiliki kewajiban yang sama untuk mengungkapkan kegiatan sosial sebagai akibat dari dampak operasional yang ditimbulkan. Lain halnya dengan leverage yang mampu memberikan kontribusi terhadap Pengungkapan CSR dimana perusahaan dengan tingkat leverage tinggi hendaknya melakukan pengungkapan kegiatan sosial seperti CSR lebih terbuka dan transparan agar mudah untuk memperoleh pendanaan dari stakeholders.

\section{Saran}

Berdasarkan kesimpulan diatas, maka penulis menyarankan untuk penelitian selanjutnya seperti sebaiknya menggunakan variabel lain selain variabel yang digunakan karena dapat dilihat penelitian ini memiliki nilai R2 rendah sebesar 9,3\%. Selain itu adanya pengaruh mengenai profitabilitas, leverage, dan ukuran perusahaan terhadap pengungkapan CSR menunjukkan bahwa terdapat perbedaan penyajian pada laporan pengungkapan CSR oleh setiap perusahaan, oleh sebab itu perusahaan perlu memiliki kesadaran untuk memberikan informasi pengungkapan sosial sebagai bentuk tanggung jawab sosialnya.

\section{DAFTAR PUSTAKA}

Al-Amin.

(2018).

https://www.walhi.or.id/index.php/cemar i-danau-mahalona-walhi-sulsel-mintakontrak-karya-pt-vale-ditinjau-ulang

As' ari, A. G. P., \& Pertiwi, T. K. (2021). Rasio Fundamental Terhadap Pertumbuhan Laba: Variabel Moderasi Ukuran Perusahaan (Fundamental Ratio On Income Growth: Variables of Company Size Moderation). Journal of Information System, Applied, Management, Accounting and Research, 5(1), 261-270.

Cahyaningtyas, F. (2018). Pengungkapan Corporate Social Responsibility (CSR) 
pada Lembaga Keuangan yang Terdaftar di BEI. Journal of Economics, Business, and Government Challenges, 1(1), 1021.

Dewi, S., \& Dita, N. (2016). Faktor-faktor Yang Mempengaruhi Pengungkapan Corporate Social Responsibility. Jurnal Ilmiah Akuntansi dan Ekonomi Volume .1. No. 3 Februari 2018 20. 3, 20-40.

Dewi, N., \& Ratna Sari, M. (2019). Pengaruh Ukuran Perusahaan, Leverage, dan Profitabilitas Pada CSR Disclosure. EJurnal Akuntansi, 27(3), 1956 - 1982.

Ghozali, Imam, 2014. Ekonometrika: Teori, Konsep, dan Aplikasi dengan IBM SPSS 22, Badan Penerbit Universitas Diponegoro, Semarang

Gunadha, $\mathrm{R}$. https://www.suara.com/news/2020/07/25 /214739/100-ha-lahan-pasca-tambangpt-timah-di-babel-dibiarkanrusak? page $=2$

Hestiningtyas, N. (2018). Pengaruh Karateristik Good Coorporate Governance dan Profitabilitas terhadap Luas Pengungkapan Corporate Social Responsibility. Repository UMY.

Mandaika, Y., \& Salim, H. (2015). Pengaruh Ukuran Perusahaan, Kinerja Keuangan, Tipe Industri, Dan Financial Leverage Terhadap Pengungkapan Corporate Social Responsibility: Studi Empiris Pada Perusahaan Manufaktur Yang Terdaftar Di Bursa Efek Indonesia Tahun 2011-2013. Jurnal Akuntansi, 8(2), 181201.

Mukhtar, A. (2019). Jurnal Economix Volume 7 Nomor 2 Desember 2019. Urnal Economix, 7, 17-24.

Ni'ami, O. D. (2018). Analisa Pengaruh Ukuran Perusahaan (Size), Profitabilitas, dan Leverage Terhadap Corporate Social Responsibility (CSR): Studi Kasus Pada Bank Umum Syariah di Indonesia Tahun 2014-2016. Skripsi.
Pakpahan, Yunus dan Lasmanita Rajagukguk. 2018. Analisis Pengaruh Profitabilitas, Ukuran Perusahaan, Ukuran Dewan Komisaris, dan Media Exposure terhadap Pengungkapan Tanggung Jawab Sosial. Jakarta: Universitas Kristen Krida Wacana. Jurnal Akuntansi. Volume 18, Nomor 2, http://ejournal.ukrida.ac.id/ojs/index.php /Akun/article/view/1631. Juni-Desember 2018

Ratmono, D., \& Sagala, W. M. (2016). Pengungkapan Corporate Social Responsibility (Csr) Sebagai Sarana Legitimasi: Dampaknya Terhadap Tingkat Agresivitas Pajak. Nominal, Barometer Riset Akuntansi Dan Manajemen, 4(2), 16-30. https://doi.org/10.21831/nominal.v4i2.79 97

Rizaldi, I. P. A., Mendra, N. P. Y., \& Novitasari, L. G. (2019). Pengaruh Corporate Social Responsibility, Profitabilitas, dan Struktur Modal Terhadap Nilai Perusahaan Di Bursa Efek Indonesia. Jurnal Riset Akuntansi (JUARA), 9(2), 112-121.

Respati, R. D., \& Hadiprajitno, P. B. (2015). Analisis Pengaruh Profitabilitas, Leverage, Ukuran Perusahaan, Tipe Industri, Dan Pengungkapan Media Terhadap Pengungkapan Corporate Social Responsibility. Diponegoro Journal of Accounting, 4(4), 1-11.

Rofiqkoh \& Priyadi, (2016). Pengaruh Profitabilitas, Leverage dan Ukuran Perusahaan Terhadap Pengungkapan Tanggung Jawab Sosial Perusahaan. Jurnal Ilmu dan Riset Akuntansi: Volume 5, Nomor 10, Oktober 2016 ISSN: 24600585. Sekolah Tinggi Ilmu Ekonomi Indonesia (STIESIA) Surabaya.

Rokhlinasari, S. (2016). Teori-teori dalam Pengungkapan Informasi Corporate Social Responbility Perbankan. Al- 
Amwal: Jurnal Ekonomi dan Perbankan Syari'ah, 7(1).

Sekaran, U, 2006, Metodologi Penelitian Untuk Bisnis, Edisi ke 4, Salemba Empat, Jakarta.

Sugiyono, 2015, Metode Penelitian Pendidikan, Cetakan ke 22, CV Alfabeta, Bandung.
Vanessa, F., \& Meiden, C. (2020). Beberapa Faktor yang Mempengaruhi CSR Disclosure Pada Sektor Pertambangan yang Terdaftar di BEI Periode 20152018. Jurnal Ilmu Komputer Dan Bisnis, 11(2), 2415-2430. https://doi.org/10.47927/jikb.v11i2.3 